\title{
lodine I 131 Monoclonal Antibody 81C6
}

National Cancer Institute

\section{Source}

National Cancer Institute. Iodine I 131 Monoclonal Antibody 81C6. NCI Thesaurus. Code C2488.

A radioimmunoconjug ate consisting of $81 \mathrm{C} 6$, a murine $\lg \mathrm{G} 2$ anti-tenascin monoclonal antibody labeled with iodine 131 (I-131), with radioimaging and radioimmunotherapeutic activities. Using monoclonal antibody 81C6 as a carrier for I-131 results in the targeted imaging and/or destruction of cells expressing tenascin. Tenascin is an extracellular matrix protein which is overexpressed in gliomas and other cancers. 